\title{
Risks of nutrigenomics and nutrigenetics? What the scientists say
}

\author{
T. Hurlimann $\cdot$ V. Menuz $\cdot$ J. Graham $\cdot$ \\ J. Robitaille $\cdot$ M.-C. Vohl $\cdot$ B. Godard
}

Received: 20 June 2013/Accepted: 18 October 2013/Published online: 29 November 2013

(c) Springer-Verlag Berlin Heidelberg 2013

\begin{abstract}
Nutrigenomics and nutrigenetics (hereafter NGx) have stimulated expectations for beneficial applications in public health and individuals. Yet, the potential achievability of such promise is not without socioethical considerations that challenge NGx implementation. This paper focuses on the opinions of NGx researchers about potential risks raised by NGx. The results of an online survey show that these researchers $(n=126)$ are fairly confident about the potential benefits of NGx, and that most downplay its potential risks. Researchers in this field do not believe that NGx will reconfigure foods as medication or transform the conception of eating into a health hazard. The majority think that NGx will produce no added burden on individuals to get tested or to remain compliant with NGx recommendations, nor that NGx will threaten individual autonomy in daily food choice. The majority of
\end{abstract}

T. Hurlimann · B. Godard $(\bowtie)$

Department of Social and Preventive Medicine,

Bioethics Programmes, School of Public Health (ESPUM),

University of Montreal, C.P. 6128, succursale Centre-ville,

Montreal, QC H3C 3J7, Canada

e-mail: beatrice.godard@umontreal.ca

T. Hurlimann · V. Menuz · J. Graham · J. Robitaille

M.-C. Vohl · B. Godard

Omics-Ethics Research Group, University of Montreal,

Montreal, QC, Canada

J. Graham

Technoscience and Regulation Research Unit (TRRU),

Department of Pediatrics, Dalhousie University,

Halifax, NS, Canada

J. Robitaille - M.-C. Vohl

Department of Food Science and Nutrition, Institute of Nutrition and Functional Foods (INAF), Laval University, Quebec City,

QC, Canada researchers do not think that NGx will lead to discrimination against and/or stigmatization of people who do not comply with NGx dietary recommendations. Despite this optimism among NGx researchers, we suggest that key risk factors raised by the socioethical context in which NGx applications will be implemented need to be considered.

Keywords Nutrigenomics · Ethics · Risks · Benefits · Researchers · Survey

\section{Introduction}

Nutrigenomics and nutrigenetics (NGx) are understood in various ways. While some narrow the definition to the study of genome/gene(s)-nutrition interactions, others broaden to the application of NGx in health promotion and disease prevention (Ronteltap et al. 2007). A distinction between nutrigenomics and nutrigenetics is often blurred by various and sometimes conflicting definitions, and both terms are still commonly used interchangeably. In this paper, "NGx" will refer to both nutrigenomics and nutrigenetics and is restricted to the study of genome/gene(s)nutrition interactions.

There is little doubt that NGx has stimulated great expectations for future beneficial applications in public health and individuals. For instance, NGx research anticipates the prevention of chronic diseases, such as cancer and diabetes, through personalized dietary interventions, engineered/modified foods that respond to consumers' specific genetic characteristics, and contribution to better public health (Ronteltap et al. 2007; Godard and Hurlimann 2009). Yet, the potential achievability of such promises is not without socioethical considerations that challenge NGx development and implementation. A cautious stance is 
consistent with the ACCE model developed by the Office of Public Health Genomics, US Centers for Disease Control and Prevention (OPHG-CDC) for evaluating analytic and clinical validity, safety, effectiveness and the associated ethical, legal and social implications of genetic tests (OPHG-CDC 2010). Ethical issues raised by NGx are considered important and debated by other authors (Chadwick 2004; Bergmann et al. 2008; Lévesque et al. 2008; Reilly and Debusk 2008; Ries and Castle 2008; Ghosh 2009; Komduur et al. 2009; Korthals 2011; Görman et al. 2013; Nordström et al. 2013). Challenges linked to the selection of participants in NGx clinical research, including claims about potential benefits, raise a cautionary call (Hurlimann et al. 2011; OMICS-ETHICS Research Group 2012, 2013; Stenne et al. 2012, 2013). Researchers investigating Dutch nutrigenomics experts' and consumers' views and expectations about NGx development emphasized the importance of taking into account all stakeholders' views (Ronteltap and van Trijp 2007; Ronteltap et al. 2008).

To this end, we surveyed NGx scientists concerning their views of the benefits and risks of NGx. While researchers' opinions about the achievability of NGx benefits have been discussed elsewhere (Stenne et al. 2013), the present paper focuses on their opinions about potential risks raised by NGx. Potential risks from NGx applications, as well as from the implementation of public health policies that would promote such applications, are considered. Our intention is not to argue that NGx and its future applications raise more concerns than other genomics/ genetics and "traditional" nutrition sciences applications, or that researchers' optimism regarding the benefits of NGx as well as their skepticism regarding its risks are unfounded. We aim to platform risk factors that should be deemed important for equal consideration by researchers, health professionals and policy makers.

\section{Subjects and methods}

This study is part of a larger project aimed at providing an empirical foundation to discern and anticipate socioethical issues associated with $\mathrm{NGx}$ research and its potential applications. In the first phase, an extensive review was undertaken of $173 \mathrm{NGx}$ clinical studies published between 1998 and 2007. Based on the NIH definition of clinical research (NIH Office of Extramural Research 2011), all interventional and/or observational studies that involved human beings as participants were considered, while studies limited to the analysis of human cells or tissues only with no other active human participation were excluded. That analysis highlighted scientific and ethical challenges of NGx research and its current or future applications (Hurlimann et al. 2011; Stenne et al. 2012). ${ }^{1}$ To ensure an in-depth interpretation of those results, we drew upon the expertise of researchers at the forefront of NGx development.

\section{Study participants}

In all, $586 \mathrm{NGx}$ researchers were invited to participate in our survey. They were (a) first or corresponding authors in NGx clinical studies published between 1998 and 2011 inclusively, (b) members of societies, associations and other research groups identified as NGx experts through an Internet Google search using the keywords "nutrigenetics" or "nutrigenomics" (e.g., International Society of Nutrigenetics and Nutrigenomics, NuGo, Nutrigenomics Consortium Netherlands, Nutrigenomik Deutschland), or their own Web site; (c) selected from among the speakers of the 4th Congress of the International Society of Nutrigenetics and Nutrigenomics; or (d) first or corresponding authors of articles on gene and food/nutrient interactions published in the Journal of Nutrigenetics and Nutrigenomics; or (e) corresponding authors of articles in the journals Gene and Nutrition and Molecular Nutrition and Food Research, identified through a search with the keywords "nutrigenetics" or "nutrigenomics" within these 2 journals.

\section{Study instrument}

We designed an English electronic survey, in which, among other questions that are not addressed in this paper, NGx researchers were asked whether they agreed (or disagreed) with 10 statements about the benefits of NGx (Fig. 1). All statements in Fig. 1, except statements 1d and 1f, were extracted from peer-reviewed scientific publications of NGx clinical study results (Stenne et al. 2012, 2013). Statements $1 \mathrm{~d}$ and $1 \mathrm{f}$, as well as statements $2 \mathrm{i}-2 \mathrm{~m}$ (Fig. 2) about the risks of NGx, were formulated by our research team.

The whole questionnaire, which was pretested among a small group of NGx researchers, took about $20 \mathrm{~min}$ to complete. Ethical approval was obtained from the Research Ethics Board of the University of Montreal. Consent to participate in the survey was presumed upon receipt of a complete questionnaire. SOM Inc. (Quebec) conducted the online survey. From January 17 to February 25, 2012, 586 researchers were sent a personalized e-mail invitation to participate in the questionnaire. A first e-mail reminder was

\footnotetext{
1 The description of the project, the methodology used in its first phase, as well as a summary of preliminary results, can be found online at http://omics-ethics.org/en/NGX-research-index (OMICSETHICS Research Group 2012, Accessed June 1st, 2013).
} 
More effective preventive and therapeutic interventions "will be developed within the context of

a nutritional genomics as new tools become available to achieve effective dietary prevention and therapy

Personalized dietary recommendations will

b become more effective through the incorporation of genetic information

Advances in NGX enable more precise public C health advice about dietary intake, supplement use, and genetic testing

$N G \times$ demonstrates that genetic risks and d predispositions to complex diseases can be modified through dietary intervention

NGx will allow the identification of individuals who e suffer from adverse reactions caused by the consumption of certain nutrients

NGx will provide health benefits to individuals who consume certain nutrients

NGx demonstrates that dietary interventions based g on genotypic knowledge are a useful strategy for the prevention of some complex diseases

NGx will increase adherence to dietary

$\mathrm{h}$ advice thanks to individualized

recommendations

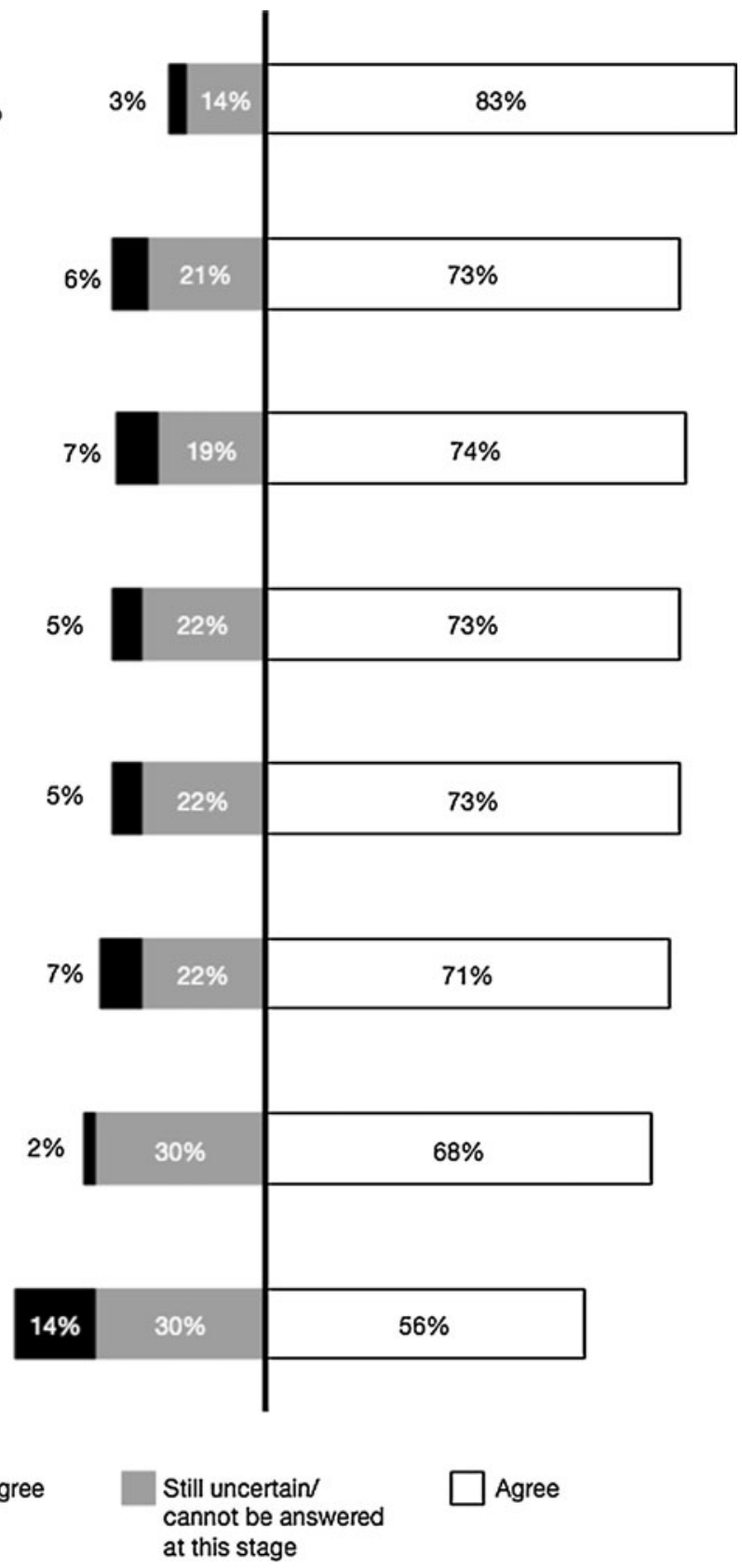

Fig. 1 Researchers' agreement with potential benefits of NGx $(n=126)$ (adapted from Stenne et al. 2013). The question reads as follows: "Please indicate your level of agreement on the following statements about nutrigenetics/nutrigenomics (NGx)"

sent to those who had not responded 1 week after the original invitation, with a second reminder 11 days later.

\section{Statistical analysis}

Cross-tabulation $\chi^{2}$ analysis produced a portrait of researchers' agreement with the proposed NGx benefits and risks, allowing us to draw comparisons between respondents according to their answers and characteristics (e.g., demographics). We considered a $P$ value of 0.05 or less as statistically significant.

\section{Results}

In all, 126 online questionnaires were completed, resulting in a response rate of $22 \%$ after two reminders, in line with the average observed in other online or e-mail surveys (Dykema et al. 2011; Dainesi and Goldbaum 2012; Viera and Edwards 2012). Researchers from 27 countries participated in the survey; $58 \%$ were from Europe, followed by $31 \%$ from North America (Table 1). Seventy-three percent of the respondents identified themselves as academic professors (Table 1). Fifty-one percent of the respondents had been 


\section{i NGx will turn food into medication \\ NGx will transform an enjoyable activity such as eating into a health hazard}

NGx will impede individuals' autonomy associated $K$ with daily food choices

NGx will place an excessive burden on individuals, because they will be responsible for being tested and remaining compliant with NGX dietary recommendations

NGx will lead to the stigmatization of, or discrimination against, people who will not comply with NGx dietary recommendations

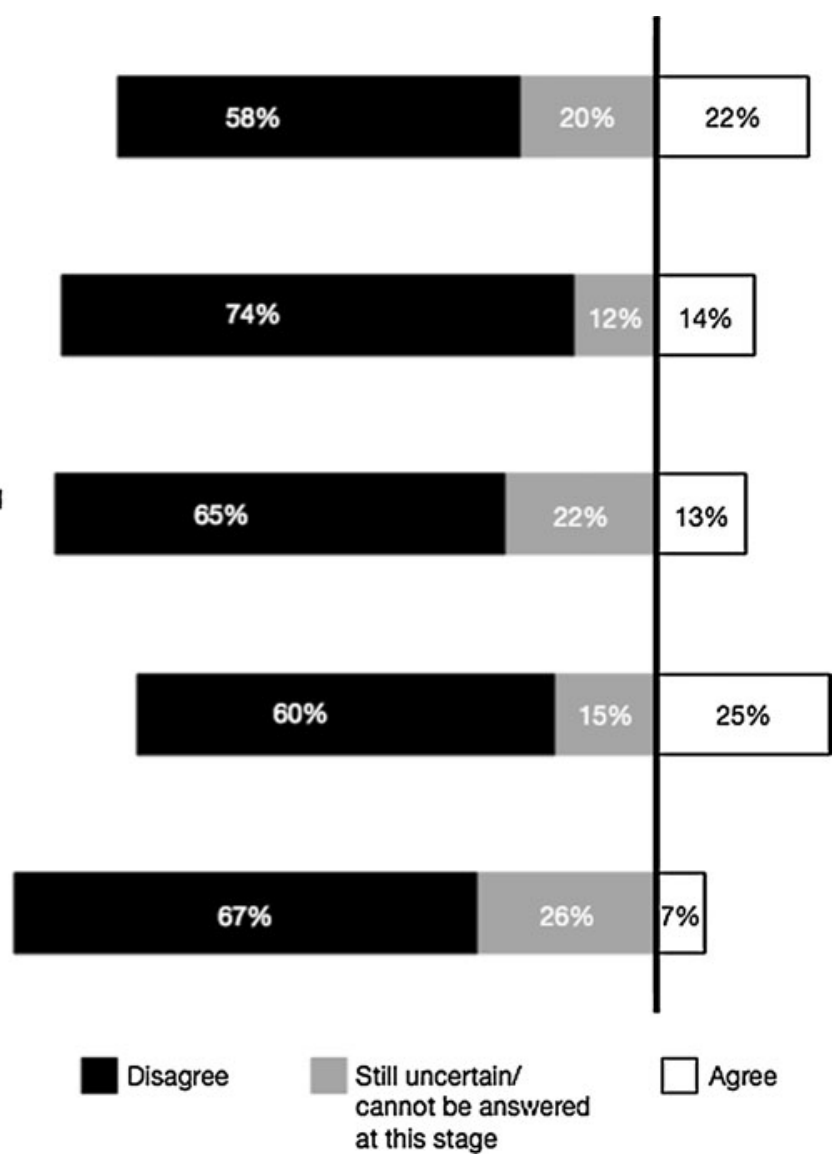

Fig. 2 Researchers' agreement with potential risks associated with the development of NGx $(n=126)$. The question reads as follows: "Please indicate your level of agreement on the following statements about nutrigenetics/nutrigenomics (NGx)"

researchers for at least 20 years. Except when explicitly reported, respondents' age, gender, affiliation or funding had no statistical significance to their answers.

A majority of researchers agreed with all the statements regarding the benefits of NGx (Fig. 1a-h). A smaller majority agreed with the idea that NGx will increase adherence to dietary advice thanks to personalized recommendations (Fig. 1h). A minority of respondents were uncertain or considered that the suggested potential benefits of NGx cannot be anticipated at this stage (Fig. 1a-h).

Researchers were invited to provide their opinion about five potential risks associated with the development of NGx (Fig. 2i-m). While a minority (12-26\%) were uncertain or considered that these 5 potential risks cannot be anticipated at this stage, the majority refuted claims that NGx "will turn food into medication," "transform an enjoyable activity such as eating into a health hazard," "impede individuals' autonomy," "place an excessive burden on individuals" and/or "lead to the discrimination against and/or stigmatization of people who would not comply with NGx dietary recommendations" (Fig. 2i-m).
Our analysis indicates that researchers who are confident about one benefit tend to be more likely to be confident about other benefits, while researchers who foresee a particular risk are more likely to anticipate other risks. Yet, researchers who are confident about the benefits of NGx are not any less likely to anticipate risks. Similarly, researchers who anticipate particular risks are as likely to be confident about potential benefits as those who do not foresee a particular risk.

\section{Discussion}

Assessment of NGx benefits

Our results indicate that the majority of NGx researchers are confident about the potential benefits of NGx and have no apprehension concerning the risks presented in the questionnaire (Figs. 1, 2). Researchers who did consider potential risks were not necessarily less optimistic about the potential benefits of NGx. Similarly, those who agreed 
Table 1 Summary of respondents' characteristics $(n=126)$

\begin{tabular}{ll}
\hline $\begin{array}{l}\text { Respondent } \\
\text { characteristic }\end{array}$ & $(\%)$ Notes \\
\hline
\end{tabular}

Gender
Male
Female
Age
$\leq 30$
$31-40$
$41-50$
$51-60$
$\geq 61$
Continent of residence
Europe $^{1}$

Europe $^{1}$

North America ${ }^{2}$
Other $^{3}$
Professional status
Professor $^{4}$

Other $^{5}$

58 'Europe: UK, Netherlands, Spain, Italy, Germany, France, Sweden, Denmark, Finland, Greece, Switzerland, Croatia, Austria, Czech, Republic, Norway, Poland

$31{ }^{2}$ North America: United States, Canada

$11{ }^{3}$ Other: Brazil, China, Malaysia, New Zealand, India, Japan, Australia, Israel, Singapore

Professional status (1)

Not specified

1

Affiliation

Private entity (part or $12{ }^{6}$ Private laboratory or organization, full) ${ }^{6}$

Public entity only ${ }^{7}$

$73{ }^{4}$ Indicated full, associate or assistant professor as at least one professional status

$26 \quad{ }^{5}$ Respondents who did not indicate "professor", and included at least one of the following: MD, postdoctoral student, research director, institute/contract research organization director/president, senior scientist, dietician, researcher, research fellow, retired, dean, $\mathrm{PhD}$ student, plastic surgeon, science communication professional, chief operating officer

\section{private hospital/clinic}

$88{ }^{7}$ University, public hospital/clinic, public research institute, nonprofit organization (e.g., trust, charity, research organization), government science laboratory

Experience in research (years)

$\begin{array}{ll}<10 & 17 \\ 10-19 & 33 \\ 20-29 & 27 \\ \geq 30 & 23\end{array}$

Diseases targeted by respondents' research

Metabolic diseases

23

(e.g., diabetes,

obesity)
Table 1 continued

\begin{tabular}{|c|c|c|}
\hline $\begin{array}{l}\text { Respondent } \\
\text { characteristic }\end{array}$ & $(\%)$ & Notes \\
\hline Cancer & 15 & \\
\hline $\mathrm{HBVD}^{8}$ & 9 & $\begin{array}{l}{ }^{8} \text { Heart and Blood Vessel Diseases } \\
\text { (HBVD) }\end{array}$ \\
\hline $\begin{array}{l}\text { Combination of the } \\
\text { preceding categories }\end{array}$ & 9 & \\
\hline Other $^{9}$ & 27 & $\begin{array}{l}{ }^{9} \text { Other diseases or fields of research } \\
\text { such as autoimmune diseases, } \\
\text { molecular nutrition, fetal } \\
\text { development, aging, gut microbial } \\
\text { gene and physiology, food safety, } \\
\text { systems biology, basic research in } \\
\text { various fields, etc. }\end{array}$ \\
\hline Not specified & 17 & \\
\hline $\begin{array}{l}\text { Respondents' research } \\
\text { conducted in: }{ }^{10}\end{array}$ & & $\begin{array}{l}{ }^{10} \text { Total }>100 \text { as some respondents } \\
\text { conduct research in }>1 \text { continent }\end{array}$ \\
\hline Europe & 64 & \\
\hline North America & 43 & \\
\hline Other $^{11}$ & 13 & $\begin{array}{l}{ }^{11} \text { Other: Australasia (Australia and } \\
\text { New Zealand), South America } \\
\text { (Brazil), Asia (China, Malaysia, } \\
\text { India, Japan, Singapore, Israel), } \\
\text { Africa (Morocco) }\end{array}$ \\
\hline Not specified & 2 & \\
\hline \multicolumn{3}{|c|}{ Sources of funding for respondents' research: } \\
\hline Public only ${ }^{12}$ & 64 & $\begin{array}{l}{ }^{12} \text { Government agencies, universities, } \\
\text { not-for-profit organizations (trusts, } \\
\text { charities, foundations, etc.), } \\
\text { European community, including } \\
\text { mentions of "European project" } \\
\text { and "International funding" }\end{array}$ \\
\hline Private (part or full) ${ }^{13}$ & 30 & $\begin{array}{l}{ }^{13} \text { For-profit companies and/or } \\
\text { private/public partnerships }\end{array}$ \\
\hline Not specified & 6 & \\
\hline
\end{tabular}

with the benefits of NGx were not more likely to disagree with its potential risks.

There is no inherent harm in being optimistic about the promises of NGx. When the claims are premature, unrealistic or exaggerated, however, they can feed into biotype detrimental to credible biomedical research (Stenne et al. 2012). Expectations related to genetic technologies have evolved and matured over time and it is now generally accepted that most diseases are subject to complex gene(s)-gene(s), as well as to gene(s)-environment interactions (Janssens and van Duijn 2008). As stated by the Centers for Disease Control and Prevention, "[d]espite significant scientific advances in genetics, researchers have only identified a small fraction of the genetic component of most diseases [and] genetic tests for many diseases are developed on the basis of limited scientific information" (OPHG-CDC 2013). A cautious stance toward the prospects for development and implementation of predictive 
genotype-based tests in clinical settings must be recommended due to these uncertainties. The NGx researchers we surveyed shared a widespread optimism for NGx, but they offered reservations about the achievability of some of purported benefits (i.e., benefits in Fig. 1a-c, e, g) within the next 5 years (Stenne et al. 2013). Moreover, NGx researchers have different and even opposite opinions about (1) the impact of the methodological limitations on the achievability of benefits and (2) the uncertainty about the long-term efficacy of future NGx interventions (Stenne et al. 2013). Researchers were equally divided as to whether NGx would increase adherence to dietary advice (Fig. 1h). While some studies suggest that personalized dietary advice may be more efficient in modifying people's eating behaviors than general dietary recommendations (Ronteltap et al. 2012), the actual impact of genetic information on nutrition-related lifestyle behavior changes is still uncertain (McBride et al. 2012; Nielsen and ElSohemy 2012; Vernarelli 2012; Fallaize et al. 2013; Görman et al. 2013; Saukko 2013). These uncertainties might explain why respondents held different views on these matters. Alternatively, our respondents were primarily scientists, who might be less compelled to make predictions based on social determinants or health promotion activities. While they can speak authoritatively about NGx technologies and scientific methods, they may regard human behavior as outside of their expertise.

These differences of opinion show that enthusiasm about the benefits of NGx shared by most researchers in the field must be qualified, appropriately nuanced, and put in perspective with alternative and, sometimes conflicting viewpoints in the NGx research community itself. While significant advances have been made in the identification of gene(s)/genome-diet interactions and genetic influences on nutrient metabolism (e.g., Lee et al. 2011), NGx research faces methodological challenges (Hesketh 2012; Qi 2012) and progress has been modest in the translation of research findings in clinical practice and public health (Minihane 2012). Much remains to be done before the benefits suggested in Fig. 1 can be considered achievable. Thus, prudence is needed despite optimistic expectations, especially when these expectations are expressed in the general terms of most of the questionnaire's examples (Fig. 1). As stated previously, expectations for NGx applications should be assessed according to their merit and with respect to their scientific credibility (Godard and Hurlimann 2009). While much research is still needed, in particular in gene-nutrition interactions in common chronic diseases, there is a growing list of well-documented examples of clinically significant nutrigenetics interactions, such as phenylketonuria (Phillips 2013), iron overload, hemochromatosis, impact of riboflavin supplementation on hypertensive individuals with the MTHFR 677TT genotype (Wilson et al. 2013) as well as risks of cardiovascular diseases associated with insufficient intake of folate by carriers of C677T and A1298C polymorphisms in the MTHFR gene (Lampe et al. 2013).

Nonetheless, the potential benefits of NGx, along with other genetic or genomic clinical applications, require balancing with potential socioethical risks. This study challenged NGx researchers to share their perceptions about some of these ethical issues. The tension between sociocultural meanings surrounding the medicalization of food and the impact of NGx on individual autonomy and responsibility warrant further attention.

Sociocultural meanings surrounding the medicalization of food

While the majority of researchers in our survey do not believe that NGx will transform food into medication, or that eating will be deemed a health hazard (Fig. 2i, j), what might the socioethical consequences of NGx be?

A "Google" search of Hippocrates' quote "Let food be thy medicine" yields more than one and a half million results, ${ }^{2}$ most linking to websites promoting-if not selling-the virtues of "healthy" food and diet for health and well-being. "Traditional" nutritional sciences have contributed to our understanding of nutritional mechanisms and of their impact on health for decades. At the same time, public health nutrition has become a key component of national and global efforts in health promotion and the prevention of chronic diseases (Lenoir-Wijnkoop et al. 2013).

NGx aspirations coincide with a recent shift in bioscience and public health agendas toward prevention and treatment of disease susceptibilities (i.e., preemptive medicine) rather than alleviation of established disease (see for instance, NIH 2008). NGx targets healthy, as well as unhealthy individuals, with or without genetic predispositions for specific diseases. At the same time, NGx, as a combination of molecular nutrition and genomics (Afman and Muller 2006) focuses on the interactions between dietary bioactive components and genetic information.

Yet, food is more than a sum of active (or inactive) components that interact (or not) with genes/genome; it is much more than a means to maintain health and reduce disease (e.g., Food Ethics Council 2005; Bergmann et al. 2008; Korthals 2011; Nordström et al. 2013). As Görman states, "[f]ood is enjoyment as well as cultural and personal identity. A meal is a social event, an important manifestation of the relationship with others. This means that food is an important aspect of human happiness and well-being, and not only an instrument for health" (Görman 2006,

\footnotetext{
${ }^{2}$ As of June 12, 2013: 1,720,000 hits.
} 
p. 16). Bisogni and colleagues conducted an extensive review of nutrition studies that provide valuable insight into diverse perceptions of food and eating related to health in various populations. It appears that "healthy eating," and consequently nutritional advice and recommendations, are often addressed in terms of their consequences in people's lives. Dietary recommendations can be perceived as obstacles: to cultural traditions and family/gender roles, to harmonious connections, to a holistic perception of health (that includes mental health, general well-being and good social/familial connections), to spiritual well-being, as well as to culturally different approaches to wellness and treatment (Bisogni et al. 2012). Similarly, dietary recommendations may be received differently - and thus be variably effective-depending on geographical, ethnical and socioeconomic factors, as well as on age, gender, household structures (single or married individuals, with or without children) and health status (Bisogni et al. 2012).

While Bisogni and colleagues may not address NGx, their review is most relevant. Qualitative research in nutrition shows that interpretations of "healthy eating" may not always match "the ways scientists discuss healthy eating" (Bisogni et al. 2012, p. 293). Other authors warn against a biomedical orientation and a reductionist approach to food and eating that nutrition sciences could embody by increasingly interpreting food in terms of disease prevention (Lang and Barling 2012; Schubert et al. 2012). In such a context, the claims made of NGx science for predicting medical conditions and reduction of risk through dietary interventions based on genetic factors that are deemed immutable must also be addressed with due considerations for familiar customs and shared meaningful relationships surrounding food that widely affect individual and community lives. NGx may target "healthy" individuals in "predisease states" identified or "measured" through genetic testing. As such, NGx may add a new genetic dimension in the quantification of risks and health and there may be a "mismatch" between how food and health are conceptualized by NGx compared to society and individuals (Komduur et al. 2009; Korthals 2011). Such incongruity may impede comprehensive development of NGx as well as its effectiveness and benefits. In the same vein, others address the dangers of the medicalization of diet and express concerns that by targeting healthy individuals and focusing on the molecular components of food and genetic predisposition of individuals, NGx might blur boundaries between health and disease, between food and drugs, and negatively alter our social relationship to food (i.e., comfort, sharing, caring and nurturing) (Food Ethics Council 2005; Görman 2006). Moreover, NGx may challenge existing legal distinctions between food and drug products (Eussen et al. 2011). New food products produced on the basis of NGx knowledge
(Görman 2006), and knowledge of traditional foods appropriated by NGx, may require new regulations related to food safety and nutritional health labeling (Ronteltap and van Trijp 2007). Issues raised by the "pharmanutrition interface" market with regard to functional foods and dietary supplements have already raised fierce debates and controversy (Eussen et al. 2011; Slashinski et al. 2012). Last but not least, lack of communication and misinformation can have harmful consequences if people choose foods instead of necessary medication, or decide not to comply with medical advice related to prescription regimens (Eussen et al. 2011, p. S6).

The statements "NGx will turn food into medication" and "NGx will transform an enjoyable activity such as eating into a health hazard" (Fig. 2i, j) are best understood within a risk framework that must be addressed alongside the development of NGx. It cannot be inferred, however, that the respondents who do not think that "NGx will transform food into medication" (Fig. 2i) or "eating into a health hazard" (Fig. 2i) would disagree with the consequences described above. Moreover, those who agree with these statements do not necessarily agree with harmful consequences. The statement "NGx will turn food into medication" (Fig. 2i) can be seen to exemplify the beneficial use of food in traditional Chinese medicine and Ayurveda (Blair et al. 2012). The use of food as a means to treat diseases or prevent their onset-with or instead of pharmaceuticals - has been rediscovered in Western societies during the last decades and the gap between pharmacology and nutrition has been narrowing (Georgiou et al. 2011). Hippocrates famous "Let food be thy medicine" can be found in peer-reviewed scientific reports, in a legitimate quest for understanding the origins of diseases and the best ways to prevent and treat them (Aggarwal and Shishodia 2006; Mitroi and Mota 2008; Gupta et al. 2010; Szarc vel Szic et al. 2010; Sung et al. 2011). Some respondents may have understood the statement "NGx will turn food into medication" as an inherently beneficial endeavor, independent of the challenges or risks such a transformation may raise.

\section{Autonomy and individual responsibility}

The majority of NGx researchers do not agree with the risks emerging to individual autonomy associated with daily food choices (Fig. 2k). Similarly, most researchers do not think that "NGx will place an excessive burden on individuals who will be held responsible for being tested and remaining compliant with NGx recommendations" (Fig. 21). In addition, a majority of them dismiss the idea that NGx would "lead to the stigmatization of, or discrimination against, people who would not comply with NGx dietary recommendations" (Fig. 2m). To avoid such 
harms, key risk factors will need to be considered alongside the development of NGx applications.

The goals of NGx coincide with public health policies toward preventative and predictive health care and an increasing focus on the personalization of health interventions and disease prevention (Brand 2011, 2012). In nutrition sciences, the idea of "personalized nutrition" is not new: nutritional recommendations have long been elaborated for specific populations and at individual levels for pregnant women, infants, patients with specific chronic diseases such as diabetes (de Roos 2012). Personalization becomes particularly relevant in genomics and genetics, including NGx (Kussmann and Fay 2008; Hesketh 2012; Rubio-Aliaga et al. 2012; Tremblay and Hamet 2013) and is "heralded the loudest by scientists" working in NGx (Penders et al. 2007, p. 333).

Public health policies and interventions, such as health promotion and disease prevention, may raise complex ethical issues that have been the subject of much debate in public health ethics (see for instance, Childress et al. 2002; Massé and Williams-Jones 2012; Rich and Ashby 2013). While a full review of these issues falls outside the scope of this paper, preventive personalized dietary interventions raise particular concern. Personalization in health care has been accompanied by the increasing role of individual responsibility in welfare state policies and endeavors (Brown 2013; Savard 2013). While this trend is arguably aimed at enhancing people's choices and empowerment in the management of their health and well-being, it also assumes that individuals "can (and should) be held morally responsible for their health outcomes" (Brown 2013, p.1). de Roos (2012, p. 50) argues that "[t]he implementation of personalized nutrition automatically means that more responsibility is given to the individuals rather that the medical/health care professionals." The UK Food Ethics Council queries whether public health policies supporting NGx and personal responsibilization will be designed to enhance people's choices. The FEC argues that under such policies, "if you know more about your genetic makeup, it implicitly constrains your choices rather than widening them" (Food Ethics Council 2005, p. 1 and 27). Others share similar concerns (Görman 2006; Korthals 2011).

Enhancing people's freedom of choice and empowerment misses the point if "essential environmental information" and every individual's "capacity for healthpromoting behavior" are not considered (Brown 2013; Tremblay and Hamet 2013). Beyond the challenge of NGx to perceptions of food, we suggest that the following considerations must be met to assess potential risks of NGx applications:

First, compliance with nutritional recommendations, whether NGx or traditional, will succeed only with equitable access to basic nutritional and "healthy" food. Health disparities resulting from food poverty and insecurity are widespread (Gartin 2012; Zeba et al. 2012, Mullany et al. 2013; Nazmi and Monteiro 2013; Zenk et al. 2013). Food access includes availability, accessibility, affordability, accommodation, and acceptability, and research is needed to better understand how these dimensions impact food environment-diet relationships and health (Caspi et al. 2012). However, knowledge from NGx research can be a powerful tool to understand the long-term consequences of underfeeding and malnutrition and could be used to improve prevention and nutrition programs targeting whole populations, including in developing countries. In this respect, NGx may fall within the global agenda that aims to improve population health, but also food security, availability, stability, and access (Godard and Hurlimann 2009).

Second, what is true for access to food is also true for access to NGx services, including genetic counseling. Significant sociodemographical differences existing between people who are aware of and use genetic tests, whether through direct-to-consumer (DTC) advertising or those administered in clinical settings, can result in health disparities (Bloss et al. 2011; Levy et al. 2011; Ortiz et al. 2011; Bellcross et al. 2012; Finney Rutten et al. 2012; Langford et al. 2012). Public policies that would promote individual responsibility for health through personalized nutrition without addressing such factors could create an inequitable and unjust burden.

Finally, empowerment and freedom of choice are merely wishful thinking if the potential users of NGx applications fear stigmatization or discrimination. The evidence for genetic discrimination, in particular in insurance and employment, is controversial, but the fear of genetic discrimination has grown (Otlowski et al. 2012). Such fears may arise from all genetic testing that could bring predictive information about diseases, in various emerging domains, including personalized medicine and pharmacogenetics (Otlowski et al. 2012). While such fears are not demonstrated in the case of NGx testing, many NGx studies focus on susceptibility genes that are well known or that were previously identified in research as genetic susceptibilities to diseases such as cancers or cardiovascular diseases (e.g., Ordovas and Corella 2004). In these studies, dietary interventions are addressed as factors that may modulate preexisting genetic risks. Such NGx testing does not fundamentally differ from testing for genetic susceptibilities to diseases and thus may also raise risks in terms of fears of discrimination and stigmatization. Perceived or actual barriers to genetic services may significantly impact public health and can lead to suboptimal care (Otlowski et al. 2012). Proposals have been made to broaden the concept of genetic discrimination in order to include a serious reflection on the potential inequities arising from a personalized medicine agenda, where genetic information 
might be used to determine access to health care (McClellan et al. 2012) or might even exacerbate health disparities (Jaja et al. 2013). Researchers have also addressed the risks of ethnic or racial stigmatization generated by genomics/ genetics and by a resurgence of "race" as a biological concept in biomedical research and clinical care (e.g., Knerr et al. 2010; Hurlimann et al. 2011; Brody et al. 2012; de Vries et al. 2012). While a full address of the controversies surrounding these issues goes beyond the scope of this paper, NGx can take no shortcuts on such matters. In addition, as shown in the previous section, dietary recommendations based on NGx may conflict with social and cultural relationships. Shared meanings for food within a community, be it geographical, familial and/or ethnic, establish borders whose crossings pose legitimate fears for marginalization, stigmatization and discrimination. Such fears-if demonstrated-will certainly present obstacles to NGx services.

\section{Limitations}

The present study is not without limitations. First, NGx research is an interdisciplinary field, with borders blurred by the complex processes under study. Thus, it is likely that our search and methodology to identify researchers in this field missed some, in particular in non-Western countries. Perceptions of NGx benefits and risks, interpretations of study results, as well as sociocultural meanings of food and health (see "Sociocultural meanings surrounding the medicalization of food"), will differ across countries. Moreover, while respondents were geographically dispersed, the survey was carried out in English only, which may have had an impact on participation rate.

Our respondents, primarily scientists, may be less familiar with social and ethical determinants that may impact benefits and risks of NGx interventions. Their answers may have been different if detailed scenarios had been explicitly provided in the survey, rather than general statements.

Nevertheless, the present study contributes to our understanding of researchers' opinions surrounding the benefits and risks of NGx and raises awareness about the socioethical context in which such risks and benefits should be addressed.

\section{Conclusion}

Our survey shows that a majority of NGx researchers do not think that NGx applications will result in the medicalization of food, turn eating into a health hazard, threaten individual autonomy in food choices or create an excessive burden on individuals to be tested and compliant with NGx recommendations. The majority of researchers also dismiss the idea that NGx will lead to the stigmatization of, or discrimination against, people who do not comply with NGx dietary recommendations. Nevertheless, while there is no current evidence of such harmful consequences in the case of NGx specifically, potential risks are raised by the socioethical context in which NGx applications will be implemented. In this respect, challenging but critical risk factors must be considered.

First, it is essential not to overlook the social relationships surrounding the meanings of food. Some authors warn against the risks raised by a biomedical orientation and a reductionist approach to food and eating in nutrition sciences (Lang and Barling 2012; Schubert et al. 2012) and NGx (Komduur et al. 2009): social dimensions need to be brought to the center of the table (Schubert et al. 2012). Much remains to be studied about the actual impact of NGx information on individuals' perceptions of food- and nutrition-related behaviors (Nielsen and El-Sohemy 2012; McBride et al. 2012; Vernarelli 2012; Fallaize et al. 2013; Görman et al. 2013).

Second, the goals of NGx coincide with public health policies promoting individual responsibility for health. Respect for freedom of choice and for social justice are crucial socioethical platforms associated with this trend. Ronteltap and colleagues, investigating Dutch NGx experts' views on the future of NGx, have shown that NGx experts anticipated the importance of freedom of choice in consumer acceptance of NGx (Ronteltap et al. 2007, 2008). Promotion of personalized nutrition interventions and of individual responsibility is, however, fatally flawed if individuals are not provided appropriate access to healthy food and NGx services. Any fear of stigmatization or discrimination can be an obstacle to NGx services and ultimately, to individual empowerment. In all cases, individuals' capacity to change nutrition-related behavior is a critical dimension in the development of NGx. Without considering these factors, not only individual autonomy and justice are threatened, but also the effectiveness of the potential NGx applications.

NGx researchers should not bear the responsibility of preventing such threats alone. NGx moves across nutrition sciences, genomics/genetics and public health, with diverse stakeholders involved in its development and implementation. All stakeholders' expertise and collaboration are needed to determine how challenges such as those discussed here will be engaged. A good start would be to require the inclusion of socioeconomic-environment considerations in the initial design of research protocols, and when acknowledging study limitations, as well as when assessing the potential benefits and risks of potential NGx interventions.

Acknowledgments The authors wish to thank Raphaëlle Stenne for her collaboration within this project and the Omics-Ethics research 
team. The authors acknowledge funding support from the Fonds de recherche du Québec - Santé (FRQS) and the Canadian Institutes of Health Research (CIHR). We are grateful to Mrs Diane Crevier and Mrs Michèle Paré, of the University of Montreal's IRSPUM (Public Health Research Institute), who were very helpful in developing the figures included in this article.

Conflict of interest Thierry Hurlimann, Vincent Menuz, Janice Graham, Julie Robitaille, Marie-Claude Vohl and Béatrice Godard declare that they have no conflict of interest.

Ethical standard All procedures followed in this study were in accordance with the ethical standards of the responsible research ethics committee at the University of Montreal and with the Helsinki Declaration of 1975, as revised in 2000 (5). Informed consent of all participants was presumed upon submission of a complete questionnaire.

\section{References}

Afman L, Muller M (2006) Nutrigenomics: from molecular nutrition to prevention of disease. J Am Diet Assoc 106:569-576. doi:10. 1016/j.jada.2006.01.001

Aggarwal BB, Shishodia S (2006) Molecular targets of dietary agents for prevention and therapy of cancer. Biochem Pharmacol 71:1397-1421. doi:10.1016/j.bcp.2006.02.009

Bellcross CA, Page PZ, Meaney-Delman D (2012) Direct-toconsumer personal genome testing and cancer risk prediction. Cancer J 18:293-302. doi:10.1097/PPO.0b013e3182610e38

Bergmann MM, Gorman U, Mathers JC (2008) Bioethical considerations for human nutrigenomics. Annu Rev Nutr 28:447-467. doi:10.1146/annurev.nutr.28.061807.155344

Bisogni CA, Jastran M, Seligson M, Thompson A (2012) How people interpret healthy eating: contributions of qualitative research. J Nutr Educ Behav 44:282-301. doi:10.1016/j.jneb.2011.11.009

Blair J, Meredith M, Plotnikoff GA (2012) Introduction to traditional Asian therapeutic diets: two enduring perspectives. Minn Med 95:45-49

Bloss CS, Darst BF, Topol EJ, Schork NJ (2011) Direct-to-consumer personalized genomic testing. Hum Mol Genet 20(R2):R132141 doi: $10.1093 / \mathrm{hmg} / \mathrm{ddr} 349$

Brand A (2011) Public health genomics-public health goes personalized? Eur J Public Health 21:2-3. doi:10.1093/eurpub/ckq197

Brand A (2012) Public health genomics and personalized healthcare: a pipeline from cell to society. Drug Metabol Drug Interact 27:121-123. doi:10.1515/dmdi-2012-0028

Brody H, Glenn JE, Hermer L (2012) Racial/ethnic health disparities and ethics - the need for a multilevel approach. Camb Q Healthc Ethics 21:309-319. doi:10.1017/S0963180112000035

Brown RC (2013) Moral responsibility for (un) healthy behaviour. J Med Ethics. doi:10.1136/medethics-2012-100774

Caspi CE, Sorensen G, Subramanian SV, Kawachi I (2012) The local food environment and diet: a systematic review. Health Pl 18:1172-1187. doi:10.1016/j.healthplace.2012.05.006

Chadwick R (2004) Nutrigenomics, individualism and public health. Proc Nutr Soc 63:161-166. doi:10.1079/PNS2003329

Childress JF, Faden RR, Gaare RD, Gostin LO, Kahn J, Bonnie RJ, Kass NE, Mastroianni AC, Moreno JD, Nieburg P (2002) Public health ethics: mapping the terrain. J Law Med Ethics 30:170-178

Dainesi SM, Goldbaum M (2012) Post-trial access to study medication: a Brazilian e-survey with major stakeholders in clinical research. J Med Ethics 38:757-762. doi:10.1136/medethics2011-100127 de Roos B (2012) Personalized nutrition: ready for practice? Proc Nutr Soc 72:48-52. doi:10.1017/S002966511200284

de Vries J, Jallow M, Williams TN, Kwiatkowski D, Parker M, Fitzpatrick R (2012) Investigating the potential for ethnic group harm in collaborative genomics research in Africa: is ethnic stigmatisation likely? Soc Sci Med 75:1400-1407. doi:10.1016/j. socscimed.2012.05.020

Dykema J, Stevenson J, Day B, Sellers SL, Bonham VL (2011) Effects of incentives and prenotification on response rates and costs in a national web survey of physicians. Eval Health Prof 34:434-447. doi:10.1177/0163278711406113

Eussen SR, Verhagen H, Klungel OH, Garssen J, van Loveren H, van Kranen HJ, Rompelberg CJ (2011) Functional foods and dietary supplements: products at the interface between pharma and nutrition. Eur J Pharmacol 668(Suppl 1):S2-S9. doi:10.1016/j. ejphar.2011.07.008

Fallaize R, Macready AL, Butler LT, Ellis JA, Lovegrove JA (2013) An insight into the public acceptance of nutrigenomic-based personalised nutrition. Nutr Res Rev 26:39-48. doi:10.1017/ S0954422413000024

Finney Rutten LJ, Gollust SE, Naveed S, Moser RP (2012) Increasing public awareness of direct-to-consumer genetic tests: health Care access, internet use, and population density correlates. J Cancer Epidemiol 2012:309109. doi:10.1155/2012/309109

Food Ethics Council (2005). FEC publishing foodethicscouncil.org website. Getting personal: Shifting responsibilities for dietary health. http://www.foodethicscouncil.org/node/110. Accessed 6 June 2013

Gartin M (2012) Food deserts and nutritional risk in Paraguay. Am J Hum Biol 24:296-301. doi:10.1002/ajhb.22270

Georgiou NA, Garssen J, Witkamp RF (2011) Pharma-nutrition interface: the gap is narrowing. Eur J Pharmacol 651:1-8. doi:10. 1016/j.ejphar.2010.11.007

Ghosh D (2009) Future perspectives of nutrigenomics foods: benefits vs. risks. Indian J Biochem Biophys 46:31-36

Godard B, Hurlimann T (2009) Nutrigenomics for global health: ethical challenges for underserved populations. CPPM 7:205-214

Görman U (2006) Ethical issues raised by personalized nutrition based on genetic information. Genes Nutr 1:13-22. doi:10.1007/ BF02829932

Görman U, Mathers JC, Grimaldi KA, Ahlgren J, Nordström K (2013) Do we know enough? A scientific and ethical analysis of the basis for genetic-based personalized nutrition. Genes Nutr. doi:10.1007/s12263-013-0338-6

Gupta SC, Kim JH, Prasad S, Aggarwal BB (2010) Regulation of survival, proliferation, invasion, angiogenesis, and metastasis of tumor cells through modulation of inflammatory pathways by nutraceuticals. Cancer Metastasis Rev 29:405-434. doi:10.1007/ s10555-010-9235-2

Hesketh J (2012) Personalised nutrition: how far has nutrigenomics progressed? Eur J Clin Nutr 67:430-435. doi:10.1038/ejen.2012. 145

Hurlimann T, Stenne R, Menuz V, Godard B (2011) Inclusion and exclusion in nutrigenetics clinical research: ethical and scientific challenges. J Nutrigenet Nutrigenomics 4:322-343. doi:10.1159/ 000334853

Jaja C, Gibson R, Quarles S (2013) Advancing genomic research and reducing health disparities: what can nurse scholars do? J Nurs Scholarsh. doi:10.1111/j.1547-5069.2012.01482.x

Janssens AC, van Duijn CM (2008) Genome-based prediction of common diseases: advances and prospects. Hum Mol Genet 17(R2):R166-173. doi:10.1093/hmg/ddn250

Knerr S, Ramos E, Nowinski J, Dixon K, Bonham VL (2010) Human difference in the genomic era: facilitating a socially responsible dialogue. BMC Med Genomics 3:20. doi:10.1186/1755-8794-320 
Komduur RH, Korthals M, te Molder H (2009) The good life: living for health and a life without risks? On a prominent script of nutrigenomics. $\mathrm{Br} \mathrm{J}$ Nutr 101:307-316. doi:10.1017/ S0007114508076253

Korthals M (2011) Coevolution of nutrigenomics and society: ethical considerations. Am J Clin Nutr 94(6 Suppl):2025S-2029S. doi:10.3945/ajen.110.001289

Kussmann M, Fay LB (2008) Nutrigenomics and personalized nutrition: science and concept. Pers Med 5:447-455. doi:10. 2217/17410541.5.5.447

Lampe JW, Navarro SL, Hullar MA, Shojaie A (2013) Interindividual differences in response to dietary intervention: integrating omics platforms towards personalised dietary recommendations. Proc Nutr Soc 72:207-218. doi:10.1017/ S0029665113000025

Lang T, Barling D (2012) Nutrition and sustainability: an emerging food policy discourse. Proc Nutr Soc 72:1-12. doi:10.1017/ S002966511200290X

Langford AT, Resnicow K, Roberts JS, Zikmund-Fisher BJ (2012) Racial and ethnic differences in direct-to-consumer genetic tests awareness in HINTS 2007: sociodemographic and numeracy correlates. J Genet Couns 21:440-447. doi:10.1007/s10897-0119478-2

Lee YC, Lai CQ, Ordovas JM, Parnell LD (2011) A database of geneenvironment interactions pertaining to blood lipid traits, cardiovascular disease and type 2 diabetes. J Data Mining Genomics Proteomics 2:1. doi:10.4172/2153-0602.1000106

Lenoir-Wijnkoop I, Jones PJ, Uauy R, Segal L, Milner J (2013) Nutrition economics-food as an ally of public health. Br J Nutr 109:777-784. doi:10.1017/S0007114512005107

Lévesque L, Ozdemir V, Gremmen B, Godard B (2008) Integrating anticipated nutrigenomics bioscience applications with ethical aspects. OMICS 12:1-16. doi:10.1089/omi.2007.0042

Levy DE, Byfield SD, Comstock CB, Garber JE, Syngal S, Crown WH, Shields AE (2011) Underutilization of BRCA1/2 testing to guide breast cancer treatment: black and Hispanic women particularly at risk. Genet Med 13:349-355. doi:10.1097/GIM. 0b013e3182091ba4

Massé R, Williams-Jones B (2012) Ethical dilemmas in health promotion practice. In: Rootman I, Dupéré S, Pederson A, O'Neill M (eds) Health promotion in Canada. Canadian Scholars' Press Inc, Toronto, pp 241-253

McBride CM, Bryan AD, Bray MS, Swan GE, Green ED (2012) Health behavior change: can genomics improve behavioral adherence? Am J Public Health 102:401-405. doi:10.2105/ AJPH.2011.300513

McClellan KA, Avard D, Simard J, Knoppers BM (2012) Personalized medicine and access to health care: potential for inequitable access? Eur J Hum Genet 21:143-147. doi:10.1038/ejhg.2012.149

Minihane AM (2012) The genetic contribution to disease risk and variability in response to diet: where is the hidden heritability? Proc Nutr Soc 72:40-47. doi:10.1017/S0029665112002856

Mitroi N, Mota M (2008) Nutrigenomics/nutrigenetics. Rom J Intern Med 46:295-304

Mullany B, Neault N, Tsingine D, Powers J, Lovato V, Clitso L, Massey S, Talgo A, Speakman K, Barlow A (2013) Food insecurity and household eating patterns among vulnerable American-Indian families: associations with caregiver and food consumption characteristics. Public Health Nutr 16:752-760. doi:10.1017/S136898001200300X

Nazmi A, Monteiro C (2013) The nutrition transition: the same, but different. Public Health Nutr 16:571-572. doi:10.1017/ S1368980013000372

Nielsen DE, El-Sohemy A (2012) A randomized trial of genetic information for personalized nutrition. Genes Nutr 7:559-566. doi:10.1007/s12263-012-0290-x
NIH (2008) Strategic vision for the future: from curative to preemptive medicine. U.S. Department of Health and Human Services Publishing NIH.gov website. http://www.nih.gov/ strategicvision.htm. Accessed 6 June 2013

NIH Office of Extramural Research (2011) Glossary and acronym list. U.S. Department of Health and Human Services Publishing NIH.gov website. http://grants.nih.gov/grants/glossary.htm. Accessed 6 June 2013

Nordström K, Coff C, Jönsson H, Nordenfelt L, Görman U (2013) Food and health: individual, cultural, or scientific matters? Genes Nutr. doi:10.1007/s12263-013-0336-8

OMICS-ETHICS Research Group (2012) Ethics and nutrigenomics research: preliminary results. OMICS-ETHICS Research Group publishing. http://omics-ethics.org/en/NGX-research-index. Accessed 6 June 2013

OMICS-ETHICS Research Group (2013) Scientific and ethical challenges in nutrigenomics/nutrigenetics research: a survey of researchers' perceptions. Final report. OMICS-ETHICS Research Group publishing. http://omics-ethics.org/docs/Report2-Nutrigeno mics-Omics-Ethics_2013.pdf. Accessed 25 Nov 2013

OPHG-CDC (Office of Public Health Genomics, Centers for Disease Control and Prevention) (2010) Genomic testing-ACCE model for evaluating genetic tests. CDC Publishing. http://www.cdc. gov/genomics/gtesting/ACCE/index.htm. Accessed 6 June 2013

OPHG-CDC (Office of Public Health Genomics, Centers for Disease Control and Prevention) (2013). Genomic testing. CDC publishing. http://www.cdc.gov/genomics/gtesting/. Accessed 6 June 2013

Ordovas JM, Corella D (2004) Nutritional genomics. Annu Rev Genomics Hum Genet 5:71-118. doi:10.1146/annurev.genom.5. 061903.180008

Ortiz AP, Lopez M, Flores LT, Soto-Salgado M, Finney Rutten LJ, Serrano-Rodriguez RA, Hesse BW, Tortolero-Luna G (2011) Awareness of direct-to-consumer genetic tests and use of genetic tests among Puerto Rican adults, 2009. Prev Chronic Dis 8:A110. http://www.cdc.gov/pcd/issues/2011/sep/10_0220.htm. Accessed 18 June 2013

Otlowski M, Taylor S, Bombard Y (2012) Genetic discrimination: international perspectives. Annu Rev Genomics Hum Genet 13:433-454. doi:10.1146/annurev-genom-090711-163800

Penders B, Horstman K, Saris WHM, Vos R (2007) From individuals to groups: a review of the meaning of 'personalized' in nutrigenomics. Trends Food Sci Technol 18:333-338. doi:10. 1016/j.tifs.2007.02.004

Phillips CM (2013) Nutrigenetics and metabolic disease: current status and implications for personalised nutrition. Nutrients 5:32-57. doi: $10.3390 /$ nu 5010032

Qi L (2012) Gene-diet interactions in complex disease: current findings and relevance for public health. Curr Nutr Rep 1:222-227. doi:10.1007/s13668-012-0029-8

Reilly PR, Debusk RM (2008) Ethical and legal issues in nutritional genomics. J Am Diet Assoc 108:36-40. doi:10.1016/j.jada.2007. 10.016

Rich LE, Ashby MA (2013) From personal misfortune to public liability: the ethics, limits, and politics of public health saving ourselves from ourselves. J Bioeth Inq 10:1-5. doi:10.1007/ s11673-013-9427-x

Ries NM, Castle D (2008) Nutrigenomics and ethics interface: directto-consumer services and commercial aspects. OMICS 12:245-250. doi:10.1089/omi.2008.0049

Ronteltap A, van Trijp H (2007) Consumer acceptance of personalised nutrition. Genes Nutr 2:85-87. doi:10.1007/s12263-0070003-z

Ronteltap A, van Trijp H, Renes RJ (2007) Expert views on critical success and failure factors for nutrigenomics. Trends Food Sci Technol 18:189-200. doi:10.1016/j.tifs.2006.12.007 
Ronteltap A, van Trijp H, Renes RJ (2008) Making nutrigenomics work-integrating expert stakeholder opinions and consumer preferences. Trends Food Sci Technol 19:390-398. doi:10.1016/ j.tifs.2008.01.012

Ronteltap A, van Trijp H, Berezowska A, Goossens J (2012) Nutrigenomics-based personalised nutritional advice: in search of a business model? Genes Nutr 8:153-163. doi:10.1007/ s12263-012-0308-4

Rubio-Aliaga I, Kochhar S, Silva-Zolezzi I (2012) Biomarkers of nutrient bioactivity and efficacy: a route toward personalized nutrition. J Clin Gastroenterol 46:545-554. doi:10.1097/MCG. 0b013e3182548df2

Saukko P (2013) State of play in direct-to-consumer genetic testing for lifestyle-related diseases: market, marketing content, user experiences and regulation. Proc Nutr Soc 72:53-60. doi:10. 1017/S0029665112002960

Savard J (2013) Personalised medicine: a critique on the future of health care. J Bioeth Inq. doi:10.1007/s11673-013-9429-8

Schubert L, Gallegos D, Foley W, Harrison C (2012) Re-imagining the 'social' in the nutrition sciences. Public Health Nutr 15:352-359. doi:10.1017/S1368980011001297

Slashinski MJ, McCurdy SA, Achenbaum LS, Whitney SN, McGuire AL (2012) "Snake-oil," "quack medicine," and "industrially cultured organisms": biovalue and the commercialization of human microbiome research. BMC Med Ethics 13:28. doi:10. 1186/1472-6939-13-28

Stenne R, Hurlimann T, Godard B (2012) Are research papers reporting results from nutrigenetics clinical research a potential source of biohype? Account Res 19:285-307. doi:10.1080/ 08989621.2012.718681

Stenne R, Hurlimann T, Godard B (2013) Benefits associated with nutrigenomics research and their reporting in the scientific literature: researchers' perspectives. Account Res 20:167-183. doi: $10.1080 / 08989621.2013 .788381$
Sung B, Prasad S, Yadav VR, Lavasanifar A, Aggarwal BB (2011) Cancer and diet: how are they related? Free Radic Res 45:864-879. doi:10.3109/10715762.2011.582869

Szarc vel Szic K, Ndlovu MN, Haegeman G, Berghe WV (2010) Nature or nurture: let food be your epigenetic medicine in chronic inflammatory disorders. Biochem Pharmacol 80: 1816-1832. doi:10.1016/j.bcp.2010.07.029

Tremblay J, Hamet P (2013) Role of genomics on the path to personalized medicine. Metabolism 62(Suppl 1):S2-S5. doi:10. 1016/j.metabol.2012.08.023

Vernarelli JA (2012) Impact of genetic risk assessment on nutritionrelated lifestyle behaviours. Proc Nutr Soc 72:153-159. doi:10. 1017/S0029665112002741

Viera AJ, Edwards T (2012) Does an offer for a free on-line continuing medical education (CME) activity increase physician survey response rate? A randomized trial. BMC Res Notes 5:129. doi:10.1186/1756-0500-5-129

Wilson CP, McNulty H, Ward M, Strain JJ, Trouton TG, Hoeft BA, Weber P, Roos FF, Horigan G, McAnena L, Scott JM (2013) Blood pressure in treated hypertensive individuals with the MTHFR 677TT genotype is responsive to intervention with riboflavin: findings of a targeted randomized trial. Hypertension 61:1302-1308. doi:10.1161/HYPERTENSIONAHA.111.01047

Zeba AN, Delisle HF, Renier G, Savadogo B, Baya B (2012) The double burden of malnutrition and cardiometabolic risk widens the gender and socio-economic health gap: a study among adults in Burkina Faso (West Africa). Public Health Nutr 15:2210 2219. doi: $10.1017 / \mathrm{S} 1368980012000729$

Zenk SN, Schulz AJ, Israel BA, Mentz G, Miranda PY, Opperman A, Odoms-Young AM (2013) Food shopping behaviours and exposure to discrimination. Public Health Nutr. doi:10.1017/ S136898001300075X 